\title{
"The wealth of nations and sustainable development: energy intensity and the environmental Kuznets curve"
}

\begin{tabular}{|c|c|}
\hline AUTHORS & $\begin{array}{l}\text { Ola Honningdal Grytten (Dttps://orcid.org/0000-0003-1416-0980 } \\
\text { R https://publons.com/researcher/1534774/ola-grytten/ } \\
\text { Magnus Lindmark (D https://orcid.org/0000-0002-3293-2318 } \\
\text { Kjell Bjørn Minde (D https://orcid.org/0000-0002-4641-380X }\end{array}$ \\
\hline ARTICLE INFO & $\begin{array}{l}\text { Ola Honningdal Grytten, Magnus Lindmark and Kjell Bjørn Minde (2020). The } \\
\text { wealth of nations and sustainable development: energy intensity and the } \\
\text { environmental Kuznets curve. Environmental Economics, 11(1), 110-123. } \\
\text { doi:10.21511/ee.11(1).2020.10 }\end{array}$ \\
\hline DOI & http://dx.doi.org/10.21511/ee.11(1).2020.10 \\
\hline RELEASED ON & Thursday, 03 September 2020 \\
\hline RECEIVED ON & Sunday, 12 July 2020 \\
\hline ACCEPTED ON & Monday, 17 August 2020 \\
\hline LICENSE & $\begin{array}{l}(c) E Y \\
\text { This work is licensed under a Creative Commons Attribution } 4.0 \text { International } \\
\text { License }\end{array}$ \\
\hline JOURNAL & "Environmental Economics" \\
\hline ISSN PRINT & $1998-6041$ \\
\hline ISSN ONLINE & $1998-605 X$ \\
\hline PUBLISHER & LLC "Consulting Publishing Company "Business Perspectives" \\
\hline FOUNDER & LLC "Consulting Publishing Company "Business Perspectives" \\
\hline
\end{tabular}

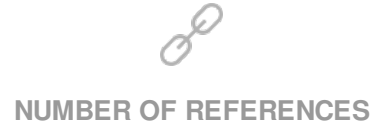

47
NUMBER OF FIGURES

12

\section{E=-}

NUMBER OF TABLES

0

(C) The author(s) 2023. This publication is an open access article. 


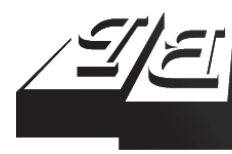

\section{BUSINESS PERSPECTIVES}

(O)

LLC "CPC "Business Perspectives" Hryhorii Skovoroda lane, 10, Sumy, 40022, Ukraine www.businessperspectives.org

Received on: $12^{\text {th }}$ of July, 2020 Accepted on: 17th of August, 2020 Published on: $3^{\text {rd }}$ of September, 2020

(c) Ola Honningdal Grytten, Magnus Lindmark, Kjell Bjørn Minde, 2020

Ola Honningdal Grytten, Professor, Dr. Econ., Department of Economics, Norwegian School of Economics, Norway.

Magnus Lindmark, Professor in Economic History, Doctor of Philosophy, Department of Geography and Economic History, Umeå University, Sweden.

Kjell Bjørn Minde, Professor, Doctor in Economics, Hauge School of Management, NLA University College, Norway.

This is an Open Access article, distributed under the terms of the Creative Commons Attribution 4.0 International license, which permits unrestricted re-use, distribution, and reproduction in any medium, provided the original work is properly cited.

Conflict of interest statement: Author(s) reported no conflict of interest

Ola Honningdal Grytten (Norway), Magnus Lindmark (Sweden), Kjell Bjørn Minde (Norway)

\title{
THE WEALTH OF NATIONS AND SUSTAINABLE DEVELOPMENT: ENERGY INTENSITY AND THE ENVIRONMENTAL KUZNETS CURVE
}

\begin{abstract}
Scholars warn that wealth leads to unsustainable environmental development. However, over the last decades, studies have shown an increase in environmental degradation at the initial stage of economic growth, and then a decline when economic growth reaches a certain level. This first acceleration and then deceleration create an inverted U-shaped curve between pollution and economic growth, called the environmental Kuznets curve (EKC). Environmental degradation can be measured by different factors. This paper deals with two of them, i.e. energy consumption and energy intensity (EI). The latter is measured as the ratio between energy consumption and GDP. The relationship of energy consumption and intensity to economic growth can serve as a tool for examining whether an EKC exists.

The paper presents continuous series of energy consumption energy intensity and gross domestic product for the Norwegian mainland economy 1835-2019. The series are used to examine the possible existence of relative and absolute environmental Kuznets curves (EKC). Time series are established using available data and annual figures for 1835-2019, which are presented for the first time. They depict a development that, first, reflects an almost constant downward trend in EI, and, second, the existence of EKCs. The paper also proposes a polynomial regression model to discuss the relationship between environmental degradation as measured by energy consumption and intensity on the one hand, and economic growth on the other. It is concluded that there are both relative and absolute EKC-relations between environmental degradation and economic growth, with 1975 as relative and 2002 as absolute turning point.
\end{abstract}

\section{Keywords}

JEL Classification

\section{INTRODUCTION}

Over the past three decades, the environmental consequences of economic growth have become an increasing concern. The main reason for this is that economic growth does not appear to reflect sustainable development.

Several research fields have been engaged in this topic, e.g. economics, economic history, environmental history and ecology. Due to the considerable fear of climate changes, in recent decades, the focus has been on the use of fossil energy and thereby air emissions of carbon dioxide $(\mathrm{CO} 2)$

During these years, the debate among scientists has become more mature and subtle. How to measure the effect of economic growth and environmental pollution, which sources to use, and calculation meth- 
ods have developed rapidly (Rothman, 1998). The central issue is how economic growth affects the sustainable environment development. Based on empirical research, two questions can be asked:

1. Is economic growth a threat to sustainable development?

2. Can it be that economic growth, up to a certain stage, has a negative impact on the environment, and then a positive one?

If the answer to the first question is yes, and there is no diminishing marginal pollution as economies move up the wealth ladder, the environment will not survive if economic growth continues. The implications of this could only be to change economic and industrial policy in a direction that alters economic growth or focuses on green growth in a steady state. The alternative would be a global breakdown.

If the answer to the second question is yes, then economic growth has a negative effect on the environment until the effect is reduced as the economy reaches a certain level of wealth. Then we deal with the so-called environmental Kuznets curve (EKC) (Stern, 2004; Dinda, 2004).

During the last decades, an important focus in environmental and economic history has been to try to find out whether economic growth follows an EKC or not. Is there any evidence that long-term economic growth can be part of the solution and not a hindrance to sustainable development?

The purpose of this paper is to map the development of EI and possible EKCs for the Norwegian mainland economy for the period 1835-2019. This is basically done by finding energy intensity (EI), i.e., how many units of energy are used to produce one unit of gross domestic product (GDP) per capita. If the EI first increases over the time series and then gradually decreases, an inverted U-shaped curve is presented, which is an EKC. If such a relationship is found, it indicates the Norwegian economy may enter the stage of environmentally sustainable development.

This paper focuses on the Norwegian mainland economy, that is, offshore oil and gas extraction, pipeline and ocean transportation are excluded both in the EI and the GDP series, as they will serve as noise in the historical data. If the petroleum industry or ocean transport were included, which mainly served other nations, it would be impossible to present underlying trends in the parameters of domestic sustainable development, since they are not consumed in Norway. Thus, they are considered external factors in the present analysis.

\section{LITERATURE REVIEW}

The EKC hypothesis stems from empirical research of the relationship between, on the one hand, economic growth and wealth, and, on the other, environmental degradation. In his global history of economic growth, Maddison (2007) mentions this theme as central to sustainable development. The modern debate started already in the 1960s and had a takeoff with the book Limits to Growth (D. H. Meadows, D. L. Meadows, Randers, \& Behrens, 1972; Wilkinson, 1973). It was stressed that natural resources one day would end, and thus, economic growth would stop. In other words, continuous growth based on consumption of natural re- sources is not sustainable. Hence, they suggested a zero-growth scenario as a steady state economy, given that this could be sustainable.

Malenbaum (1978) challenged this view by showing that the demand for certain metals fell as proportion to GDP in wealthy countries. Assuming the same development in the future, the author drew a picture showing that economic growth did not have to end up in an environmental disaster. Research by Auty (1985) confirmed this view. An Intensity of Use (IOU) hypothesis was put forward, suggesting that use of natural resources could be an inverted U-shaped curve along with economic growth. Williams, Larson, and Ross (1987) and 
Tilton (1990) concluded that even the use of energy could fall along with economic growth in mature economies.

The Kuznets curve was already known as the inverted U-shape between economic growth and inequality, suggesting inequality first increases by economic growth, and after the economy reaches a certain point, inequality drops with growth. One of the first studies of the empirical relationship between air pollution and economic growth was carried out by Grossman and Krueger (1991). During the early 1990s, the term EKC was also increasingly used for the relationship between environmental degradation and economic growth.

In 1987, the United Nations (UN) launched their report Our Common Future (UN, 1987). It was concluded that economic growth could be a solution to poverty. However, growth had to be ecologically sustainable. Thus, it was imperative that growth should not lead to environmental degradation. Central in this reasoning has been a change of focus from natural resources to environmental resources, in particular, climatic challenges. Beckermann (1992), Bhagawati (1993), Panayotou (1993) and Nemat (1994) showed by empirical evidence that the phenomenon could be possible to obtain. Arrow, Bolin, Costanza et al. (1995) concluded that entering into a mature and wealthy economy would mean more emphasis on service industries and less on manufacturing industry, leading to relative less environmental degradation as economic growth continues. Bruvoll and Fæhn (2005) argue that increased wealth makes consumers more willing to pay for clean nature, and therefore environmental degradation may decrease with increased wealth.

More recent research has focused on the EKC itself, and most scholars doing research in this field find a relationship confirming a relative decoupling between growth and environmental degradation at a certain stage of wealth (Harbaugh, Levinson, \& Wilson, 2002; Bimonte \& Punzo, 2005; Ciegis, Streimikiene, \& Zavadskas, 2008; Mills \& Waite, 2009; Uchiyama, 2016; Koilo, 2019a).

If one sees growth convergence in the coming decades, that is, developing countries will have higher growth rates than developed countries, it is reasonable to assume they will also enter the EKC-relationship. Thus, economic convergence might mean environmental convergence. This assumption was labeled the Double convergence hypothesis (Bimonte, 2009). However, one has to remember this will depend on the causal reasons for the empirical tracks of the EKC. If one does not find similar environmental focus in the developing countries, they may not be able to enter the turning point as easily as others. This will depend on political, consumption and business attitudes (Stern, 2004; Copeland \& Taylor, 2004; Spangenberg, 2001).

The energy intensity (EI) of GDP describes the relationship between GDP in fixed prices and energy consumption. Long-term trends show a dynamic relationship between the two. Studies have identified different phases over time. For countries like the UK, Germany, France and the USA the industrialization process was based on coal as the energy source. They show a steep increase in domestic EI in the early phase, thereafter a peak followed by a pattern of falling EI (Schurr \& Netschert, 1978; Smil, 2000; Kander, Malanima, \& Warde, 2013; Smil, 2016). Fall in EIs can be interpreted as indications of relative or total decoupling of the positive relationship between economic growth and environmental pollution. Energy consumption is often considered a proxy for the environmental impact (Stern, 2004). However, such impact varies greatly between energy sources.

Gales, Kander, Malanima, and Rubio (2007) have shown that per capita energy consumption increased in the Netherlands and Sweden from the mid 1800s to the early 1970s. Kander (2002) concluded surprisingly that, in the case of Sweden, the EI started its fall relative to GDP as early as the 1800 s. She also finds an absolute fall of some important pollution factors. Thus, one can depict an absolute EKC. Kunnas and Myllyntaus (2017) find a similar pattern for Finland, while Nakicenovic, Grubler, and McDonald (1998) reveal a long-term decline in EI for the USA. It can be argued that this special pattern for the Nordic countries and North America can be explained by the fact that house heating played an important role in energy consumption even before takeoff of economic growth. Warde (2019) points out that the data for the 19th century often lacks reliability due to courageous assumptions behind the estimations. 
As for Norway, little has been done to investigate the historical energy intensity. Thus, this study contributes to filling this gap for the period 1835-1990. A pioneer in the area was Stoltz (1955) who gave his estimations of the Norwegian EI for the period 1900-1950. Stoltz reported growth in the energy consumption, but a fall in EI for the period. However, he stressed that the period saw a lot of noise due to the two world wars and severe depressions in the early 1900 s, the 1920s and the 1930s. Hence, one should be careful to draw conclusions based on his calculations.

Grimstad (2019) later made estimates for the period 1990-2017 and said that the EI for mainland Norway showed a downward trend from the departure in 1990. Recently, Koilo (2019b) has studied the relationship between $\mathrm{CO} 2$ emissions, energy consumption and intensity and growth of the Norwegian maritime sector. She concludes there is an EKC relationship between the use of energy, $\mathrm{CO} 2$ emissions and value-added growth in the Norwegian merchant fleet.

\section{METHOD}

The EKC hypothesis rests on an empirical relationship between wealth and pollution. From an economic theory perspective, this relationship can be explained as a combination of technical development and preferences (Johansson \& Kriström, 2007). At the same time, several dynamic parameters become exogenous in such models, e.g., the question of which factors impact preferences and if the preferences are cointegrated with the technical development. In addition, these models are general, as they do not consider how environmental preferences are channeled: through political, self-regulation, technological or free market channels.

This paper focuses on energy intensity (EI), that is, how much energy is consumed per unit of GDP. Energy consumption is not synonymous with environmental pollution. However, it is related to degrading of the environment, e.g., via climate changes. Energy production is also very often based on fossil fuel, with significant omissions of $\mathrm{CO} 2$, sulfur dioxide and different air particles. Hydro power, on the other hand, has a marginal impact on the climate, but may have significant biological disadvantages.
EI is a partial productivity measure. It can serve as an indicator of environmental degradation and therefore an indicator of negative sustainable development (Arrow et al., 2004; Hartwick, 1977). Energy is also part of the capital stock. Higher EI then gives higher capital stock, which in its turn might give higher economic growth. Thus, an increase in EI might serve as a negative proxy for sustainable environmental development and a positive proxy for sustainable economic development.

\subsection{Theory}

The EKC theory is based on empirical research, suggesting that early economic growth causes environmental degradation. This degradation continues until a certain level of wealth is obtained. Then one might see signs of reduced degradation. Empirically, this is basically shown in increasing degradation during takeoff phases of the economy. However, the marginal degradation can be negative or become negative at the stage of economic growth. This relationship may indicate that an increase in wealth at a certain stage can reduce even the aggregated level of environmental degradation (Dinda, 2004).

\subsection{Formalization}

Theoretically, there are two major forms of the EKC, as illustrated in Figure 1. The most common deals with a relative EKC, that is, marginal degradation of the environment will first increase and then decrease with economic growth. An absolute EKC, where the aggregated level of degradation first increases with economic growth and then decreases, is supposed to be less frequent.

A relative EKC relationship implies that economic growth may be a partial solution to environmental degradation, but not sufficient when an absolute relationship implies that economic growth can be a solution to environmental degradation.

The situation when environmental degradation no longer goes hand in hand with economic growth is called the turning point or decoupling between economic growth and environmental degradation.

In the research literature one may also find the terms a weak and a strong EKC. However, these are not al- 

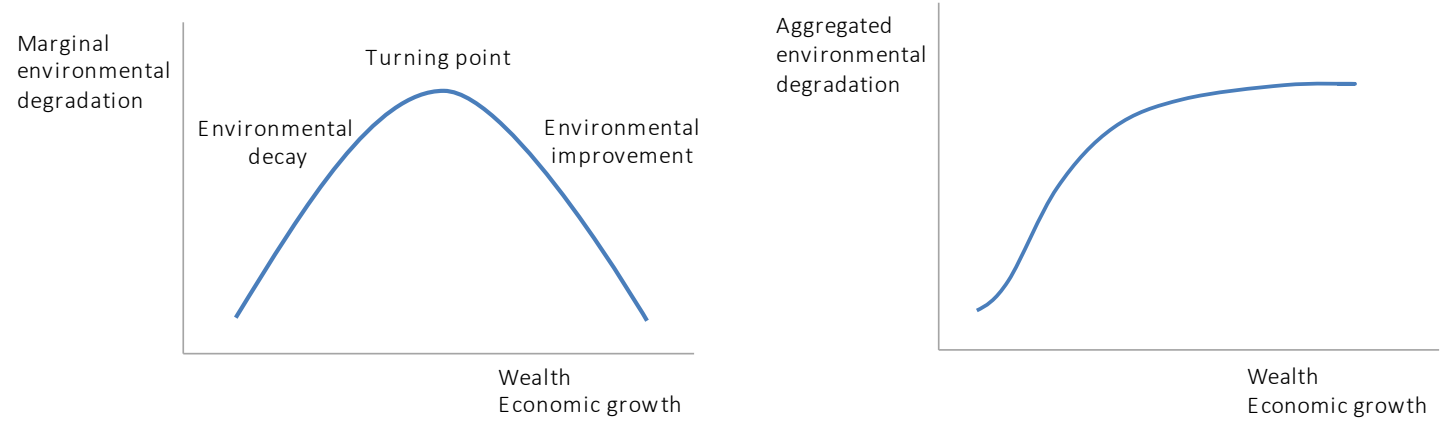

Figure 1a. Relative EKC
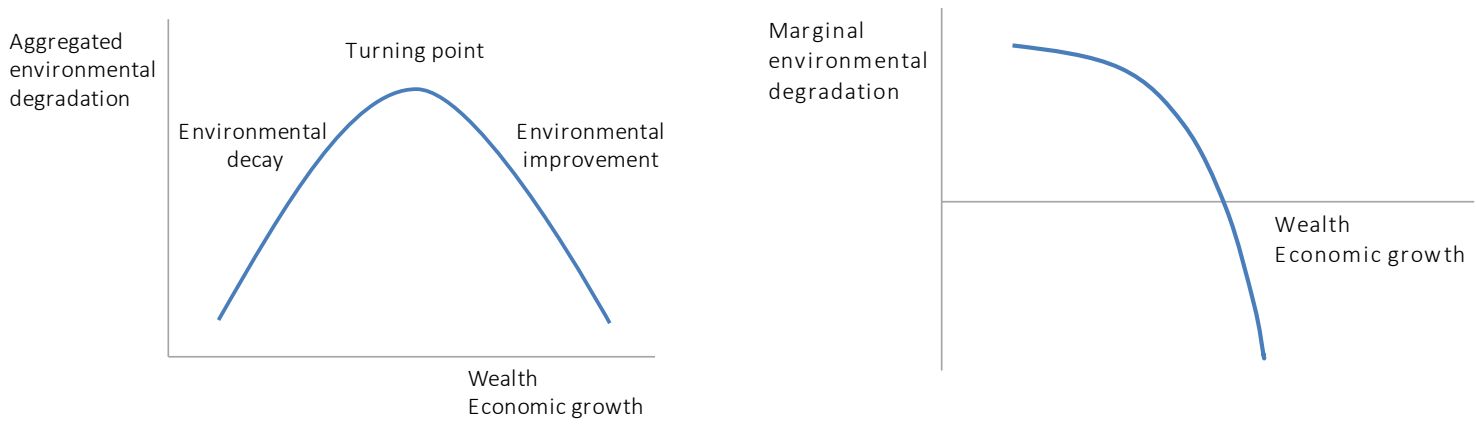

Figure 1b. Absolute EKC

Figure 1. Relationship between wealth (economic growth) and environmental degradation in the EKC

ways given the same definitions (Kander, 2002). This paper uses the term strong relationship when the environmental degradation falls with a higher rate than the economic growth, and a weak relationship describes a lower fall in the degradation than in the economic growth. This might be both at the marginal and the aggregated or absolute level.

So how can one explain the link between economic growth and reduced environmental degradation? The following four major links can be formulated:

\section{Technological}

Technological innovations can introduce the way for profitable clean energy, and thus, less environmental pollution.

\section{Political}

This implies that states have sufficient economic resources for politicians to take action to reduce environmental degradation.

\section{Standard of living}

This implies consumers become wealthy enough to demand a better and more sustainable development.

\section{Economic growth}

Economic growth in itself shifts consumption over to more environmentally friendly products, and productivity makes cleaner production possible.

This paper does not focus on the credibility of these explanations. However, all have been decisive factors. Economic growth and increased environmental pollution are increasingly attracting the attention of politicians, consumers and business itself. Politicians take measures to improve the environment, consumers demand for environmentally friendly products, and the industry seeks to apply more environmentally sustainable technology in production. 


\subsection{Model}

To calculate EI for Norway 1835-2019, both energy consumption and GDP data are needed. Energy consumption is calculated via an EGP-network standard to Joule, a derived unit of energy. The authors' method originates from the IPAT-identity, where $I$ is the environmental impact, which is influenced by size of population $(P)$, wealth $(A)$ and technology $(T)$ (Chertow, 2000) as a tool for analyzing long-term energy effects. The method is quite straightforward, as energy intensity (EI) is the share of total consumption of energy $\left(E_{t}^{C}\right)$ of GDP $\left(Y_{t}\right)$ in period $t$ :

$$
E I_{t}=E_{t}^{C} / Y_{t}
$$

Energy consumption in period $t\left(E_{t}^{C}\right)$ is a proximity of the environmental impact $\left(E_{t}^{I}\right)$ and is a function of population $(P)$, wealth, which in this paper is GDP $(Y)$, and finally technology $(T)$ in period $t$ :

$$
E_{t}^{I}=E_{t}^{C}=F\left(P_{t}, Y_{t}, T_{t}\right)
$$

One can operationalize this relation geometrically, by multiplying the right-side parameters with each other:

$$
E_{t}^{I}=E_{t}^{C}=\left(P_{t}^{x}, Y_{t}^{x}, T_{t}\right) .
$$

Furthermore, $E I$ can be expressed as an elasticity $\left(E I^{e}\right)$ :

$$
E I^{e}=\frac{d E_{t}^{C}}{d Y_{t}}=\frac{E_{t+n}^{C} / E_{t}^{C}}{Y_{t+n} / Y_{t}} .
$$

Empirical research shows that $E I$, or $E^{C}$, normally increases when production, or GDP $(Y)$, increases. This is called coupling, as expressed in equation (4):

$$
d\left(E_{t}^{C} / Y_{t}\right)>0
$$

Expansive coupling takes place when energy consumption increases faster than GDP.

$$
\frac{E_{t+n}^{C} / E_{t}^{C}}{Y_{t+n} / Y_{t}}>1
$$

Relative decoupling takes place when

$$
d\left(E_{t}^{C} / Y_{t}\right)<0 .
$$

The increase in $\mathrm{Y}$ will be larger than the increase in energy consumption:

$$
0<\frac{E_{t+n}^{C} / E_{t}^{C}}{Y_{t+n} / Y_{t}}<1 .
$$

Absolute decoupling requires that energy consumption $\left(E^{C}\right)$ decreases when GDP $(Y)$ increases:

$$
-1<\frac{E_{t+n}^{C} / E_{t}^{C}}{Y_{t+n} / Y_{t}}<0 .
$$

Absolute strong decoupling implies energy consumption falls more than GDP increases:

$$
\frac{E_{t+n}^{C} / E_{t}^{C}}{Y_{t+n} / Y_{t}}<-1
$$

This paper pays attention both to relative and absolute decoupling. In sum, energy intensity is calculated as energy consumption relative to gross domestic product per capita for all years 18352019. The paper then attempts to find out if an increase in intensity during the first phase and then a decrease in intensity can be recognized. If such a relationship is found, it is a sign of an increase in marginal environmental degradation in the first period and a decrease in marginal environmental degradation in the second period. The paper also seeks to find out if absolute decoupling has taken place by relating energy consumption per capita to economic growth. If energy consumption per capita first increases and then falls relative to economic growth, then there is an absolute EKC relation.

In sum, the paper seeks to find whether there was an environmental Kuznets curve for Norway along these parameters for the period and therefore a decoupling of the positive relationship between economic growth and environmental degradation.

\section{RESULTS}

To draw conclusions about the statistical relationship between economic growth and environmental degradation, it is necessary to establish time series of energy consumption, energy intensity and economic growth and follow the pattern of these series, as is done in this section of the paper. 


\subsection{Data}

The data for the energy consumption estimations are primarily taken from Lindmark and Minde (2018), while the historical GDP series are compiled from Grytten (2020). The series are presented in Figure 2. As already stated, the paper uses series for mainland Norway. The graphs depict substantial growth in both measures. However, one can notice the energy consumption is leveling out from around 2000, while GDP continues its growth. This may be an indication of decoupling between the two.

Energy consumption data are basically taken from governmental papers until the 1870s and later from Statistics Norway. The reliability of these records seems satisfactory until 1876, good for 1876-1920, and very good since 1920 . Their quality is considered to be of the same high standard as for other Nordic countries, and possibly higher (Lindmark \& Minde, 2018). The main challenge is the estimations of traditional fuel, like wood, peat and me- chanical hydro energy, which are made based on the calculated energy consumption for commodity consumption and production. Lindmark and Minde (2018) also transformed the data from kilowatts per hour $(\mathrm{kWh})$ to Joule $(\mathrm{J})$, where $1 \mathrm{kWh}$ $=3 \cdot 6 \cdot 10^{6} \mathrm{~J}$. They have been transformed data to Gigajoule (GJ), where $1 \mathrm{GJ}=1 \mathrm{~J} \cdot 10^{9}$, and Petajoule $(\mathrm{PJ})$, where $1 \mathrm{PJ}=1 \mathrm{~J} \cdot 10^{15}$.

Energy consumption for the Norwegian mainland economy is reported as nine different sources of production. Five of these are traditional sources, those are energy from horses, humans, mechanical hydropower, peat and firewood (wood). Four are newer sources of energy, i.e., coal, electricity, gas and oil. Since 2012, energy consumption and EI figures by Grimstad (2019) and Statistics Norway have been used. It is not a straightforward operation linking the different sources, due to structural breaks in data caused by change of definitions. However, by splicing the series by level in 2002, one obtains annual series of energy consumption and intensity for 1835-2019. It should be

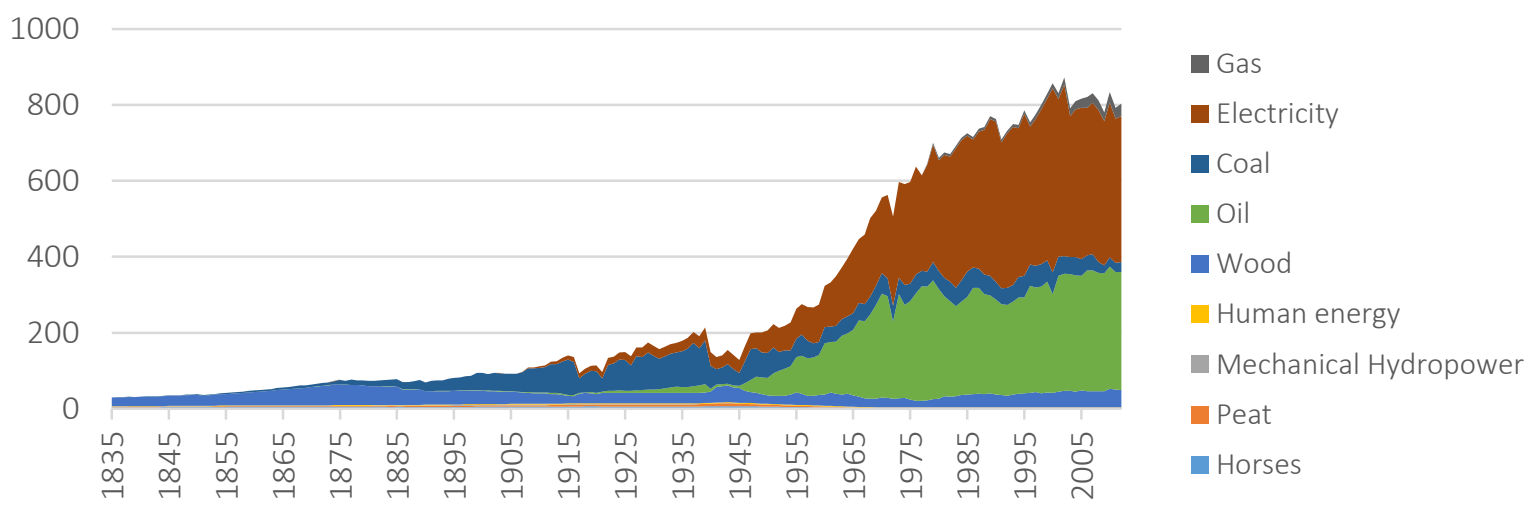

Figure 2a. Energy consumption by source of production in Petajoule derived units, 1835-2012

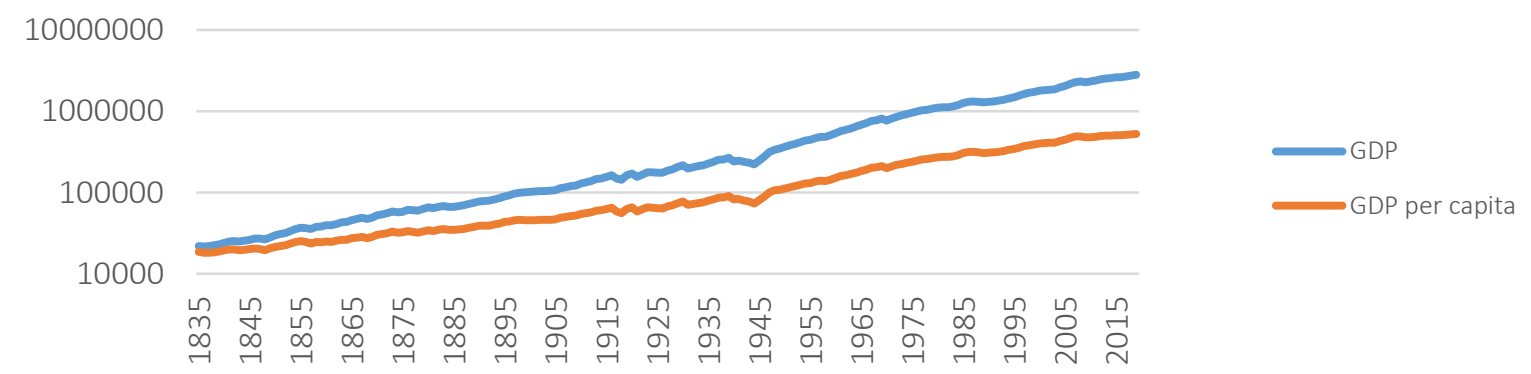

Figure 2b. GDP in 2015-NOK, 1835-2019 (semi-logarithmic scale)

Figure 2. Historical energy consumption and GDP for Norway 
noted that the introduction of coal in the $1800 \mathrm{~s}$ made the environmental footprints of energy consumption more negative, while hydroelectricity from the late $19^{\text {th }}$ century had the opposite effect.

GDP data in this study stems from an ongoing project at the Norwegian central bank. Drawing data from public and private records, and from the Wedervang Historical Archive of Prices and Wages, one establishes a detailed set of value added for the Norwegian economy during a 200-year period. From 1946, the national accounts by Statistics Norway have been used (Skoglund, 2009). By drawing from these rich sources of data and applying a double deflation technique, i.e., deflating both input and output series to obtain fixed price series, these GDP series seem more valid and reliable than most historical national accounts.

They are calculated in base values on the production side and market values on the expenditure and production, including product taxes and subsi- dies. From 1970, the series split between mainland Norway and the Norwegian economy as a whole. This is due to the merchant fleet and the offshore oil and gas activity, including pipeline transportation, which are excluded from the estimates for the Norwegian mainland economy. The paper uses GDP for mainland Norway for the entire period.

\subsection{Energy consumption and intensity}

Now, appropriate estimates of the relationship between EI and GDP can be made as indicators of possible EKCs. Figure 2 shows that energy consumption increased slowly until hydroelectricity had its breakthrough after 1905. Due to the two world wars, the huge spurt did not arrive until the 1950s, it started to level out in the 1990s and reached maximum in 2002. Thereafter, energy consumption in the Norwegian mainland economy stopped its increase or even stagnated. This definitely gives the EKC can be traced, not only in relative terms, but also in absolute terms.

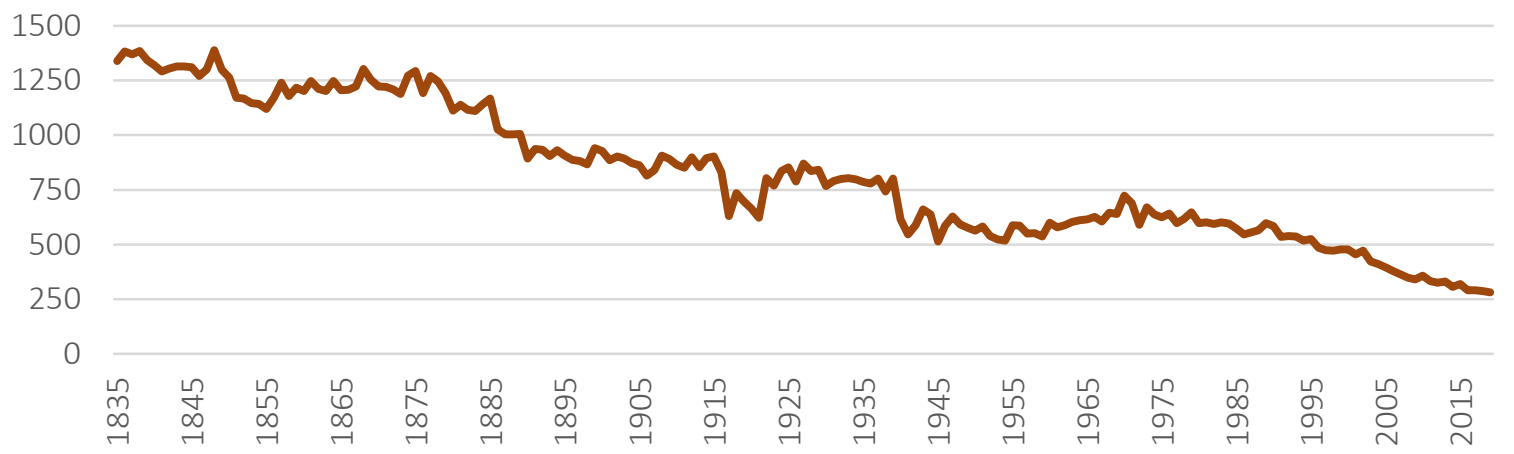

Figure 3a. Energy intensity in Gigajoule derived units per GDP in 2015-NOK

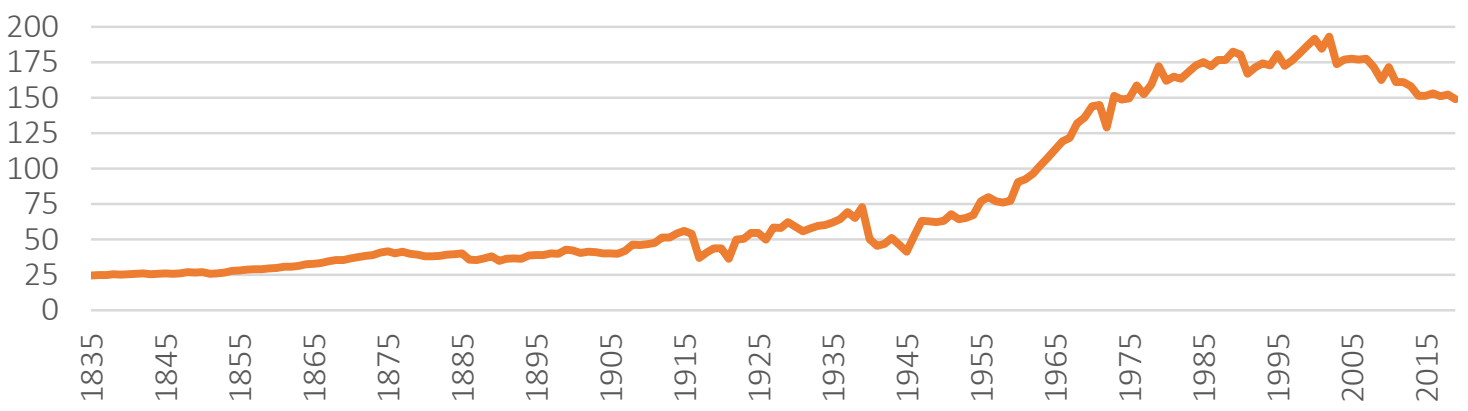

Figure 3b. Energy consumption per capita in billion Gigajoule derived units

Figure 3. Energy intensity and consumption, 1835-2019 
To come closer to the core of the present analysis, it is necessary to calculate both energy intensity (EI) and energy consumption per capita during the period of investigation (see Figure 3). The results might be somewhat surprising. Firstly, an almost constant trend of falling energy intensity is found, except for the industrialization waves in the 1860-1870s, 1890s-1914 and the 1950s until the early 1970s. Also, low EIs are found during the world wars. This suggests minor EKCs with increased environmental degradation during periods of industrialization, and thereafter decreased degradation in periods of less industrialization in 1855-1900 and 1920-1940. There is a major wave in 1950-2019, first with industrialization and thereafter deindustrialization from the mid 1970s. In other one finds, evidence of a relative EKC in 1950-2019 with turning point in 1975.

As for energy consumption per capita, a clear hint of an EKC is found. From 1835, and in particular from the early 1950s, a significant increase in energy consumption per capita can be found followed by a quite evident stagnation from the first years of the present century. This clearly shows the development in EI for this period, which also shows the absolute EKC curve for mainland Norway since the 1830s until present days, with 2002 as its turning point.

\section{DISCUSSION}

The reliability of the data set seems satisfactory until 1876, then good until 1920 and finally very good since 1920 . However, validity may be a bit more problematic. In the first place, one can ask how good parameters of energy consumption and intensity are for environmental degradation, as they are proxies rather than direct measures. Second, different kinds of energy sources give different volumes of emissions. Hence, energy consumption and intensity are not necessarily telling a story of environmental degradation. Rather they give indications. By following a limited period with quite similar sources of mainland energy consumption, a more valid time data set is obtained. Thus, the paper examines the period 1950-2019.

To discuss the consequences of the calculations and the relationship between energy consumption and economic growth, one can look at the statistical relationship between the two variables. Hence, this study presents these as plot diagrams and estimations of polynomial regressions to discuss trends in the time series. The polynomial regression model of order $m$ is established according to equation (11), where $y$ denotes the estimated value at $i, x$ denotes the regression parameters of the model, and is the disturbance term:

$$
\begin{aligned}
& y_{i}=\beta_{0}+\beta_{1} x_{i}+\beta_{2} x_{i}^{2}+\beta_{3} x_{i}^{3}+\ldots \\
& \ldots+\beta_{m} x_{i}^{m}+\varepsilon_{i},
\end{aligned}
$$

where $(i=1,2,3, \ldots, n)$.

This can be expressed in a matrix form:

$$
\left[\begin{array}{c}
y_{1} \\
y_{2} \\
y_{3} \\
\vdots \\
y_{n}
\end{array}\right]=\left[\begin{array}{ccccc}
1 & x_{1} & x_{1}^{2} & \ldots & x_{1}^{m} \\
1 & x_{2} & x_{2}^{2} & \ldots & x_{2}^{m} \\
1 & x_{3} & x_{3}^{2} & \ldots & x_{3}^{m} \\
\vdots & \vdots & \vdots & \ddots & \vdots \\
1 & x_{n} & x_{n}^{2} & \ldots & x_{n}^{m}
\end{array}\right] \cdot\left[\begin{array}{c}
\beta_{0} \\
\beta_{1} \\
\beta_{2} \\
\vdots \\
\beta_{m}
\end{array}\right]+\left[\begin{array}{c}
\varepsilon_{1} \\
\varepsilon_{2} \\
\varepsilon_{3} \\
\vdots \\
\varepsilon_{n}
\end{array}\right] .
$$

When using pure matrix notation, one can express each of the four parameters and factors in equation (12) as in equation (13):

$$
\vec{y}=\mathrm{X} \vec{\beta}+\vec{\varepsilon},
$$

where $\vec{y}$ is a response vector, $\mathrm{X}$ is a design matrix, $\vec{\beta}$ is a parameter vector, and $\vec{\varepsilon}$ is a random error vector. The vector of estimated polynomial regression coefficients $(\vec{\beta})$ using OLS estimation would be:

$$
(\hat{\vec{\beta}})=\left(X^{T} X\right)^{-1} X^{T} \vec{y} .
$$

In this analysis, the dependent variable, $y$, is energy consumption per capita or energy intensity, when the explanatory variable is GDP per capita. It is now possible to run tests according to the model, which throw light on the findings in the section above. The results are illustrated by a plot diagram and the regression esimations in Figure 4.

The relationship between EI and GDP per capita in fixed prices seems to be similar to a N-shape, which often is the case for the historical development in modern economies. Initially, there is drop in the EI curve due to the substitution of wood and peal for cleaner energy. Then, possible evidence of the EKC 
Source: Lindmark and Minde (2018), Grytten (2020).

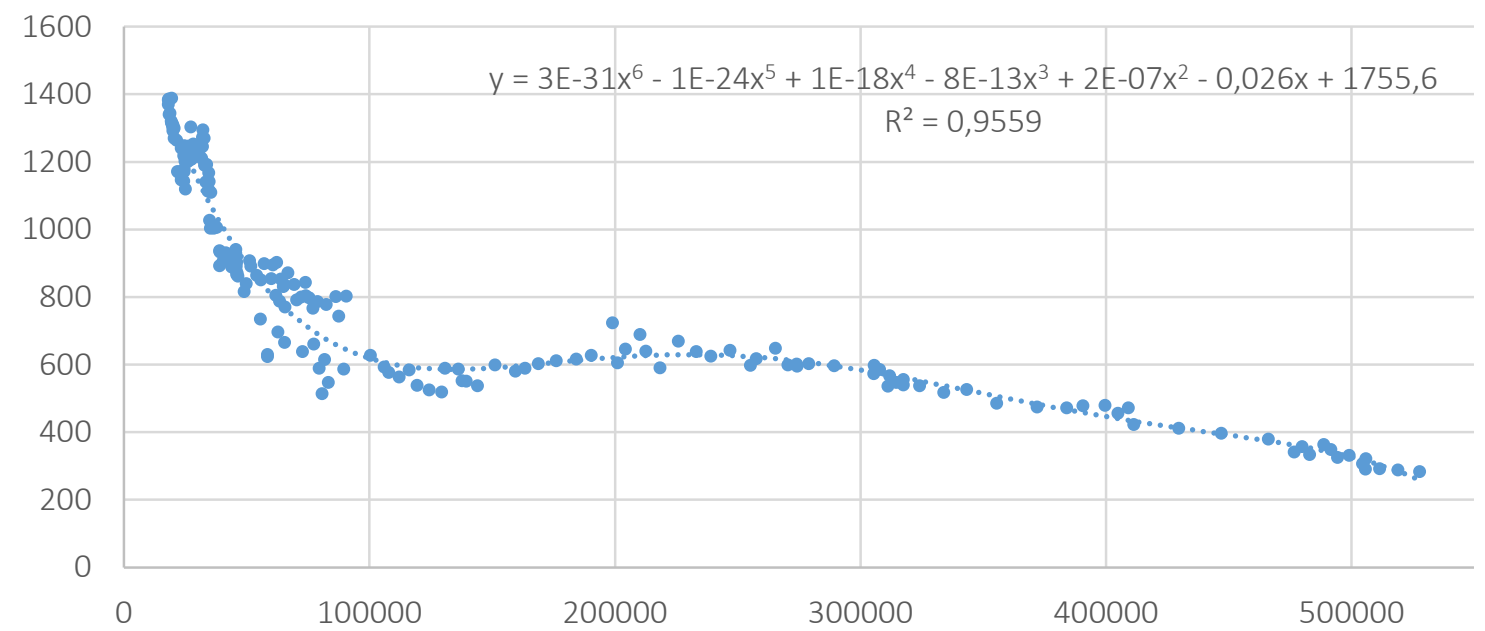

Figure 4. Energy intensity in Gigajoule derived units vs GDP per capita in 2015-NOK, 1835-2019

is found, as the economy goes through substantial industrialization and growth until the development in EI levels out and falls. As for mainland Norway, it appears that the initial fall ends at a GDP per capita level of 130.000 in the early 1950s, and then the increase continues until a per capita GDP level of 220.000 in the mid 1970s, both figures in 2015-NOK.

One should look at a smaller sample to discuss a possible EKC. Thus, the 1950-2019 model is applied, using independent data series for this period by estimating for these limited years only. The results of the regression estimations and the corresponding plots are shown in Figure 5. The polynomial regression line, along with the plot diagram, evidently shows a relative environmental Kuznets curve for the Norwegian mainland economy based on the relationship between economic growth and energy intensity for 1950-2019. Following both the energy intensity and per capita consumption along a timeline, one finds 1975 as the exact turning point.

Finally, in addition to the relative EKC, an absolute EKC can also be traced. To find out if such a relationship exists, it is natural to organize the relationship between energy consumption per capita and GDP per capita for the period under investigation and run the polynomial regression model on these data. The results of the regression estimation are reported in Figure 6. The polynomial regression line clearly

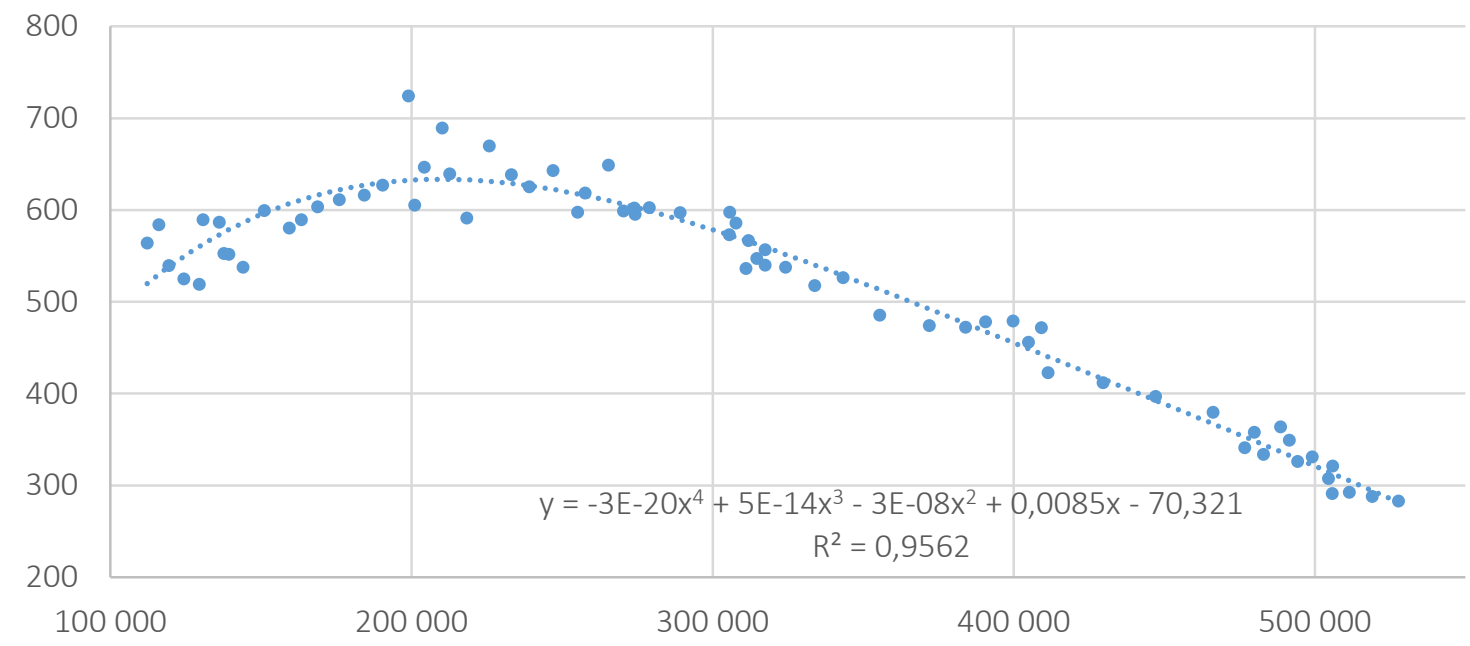

Figure 5. Energy Intensity in Gigajoule derived units vs GDP per capita in 2015-NOK, 1950-2019 


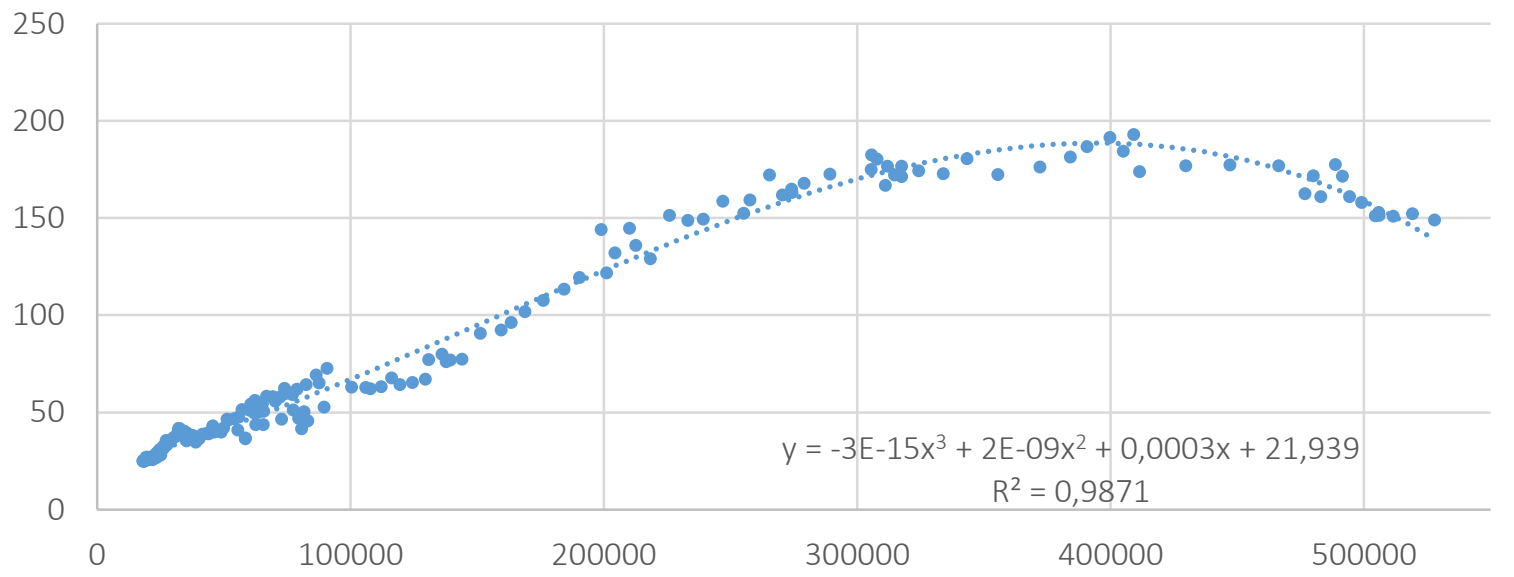

Figure 6. Energy consumption per capita in Gigajoule derived units vs GDP per capita in NOK-2015, 1835-2019

depicts that the entire 1835-2019 period represents an absolute EKC curve with a turning point or decoupling during the first years of the $21^{\text {st }}$ century.

Regarding the tests performed within the regression model, one can find very satisfactory $R^{2}$ - levels, that is, the estimated regression lines explain between $95.59 \%$ and $98.71 \%$ of the development. Thus, it seems evident that the historical development of the EI along with economic growth for mainland Norway indicates EKCs, both in relative and absolute terms.

\section{CONCLUSION}

This paper seeks to investigate the possible relationship between environmental degradation and economic growth. More precisely, it aims to study historical trends in energy intensity and if there is an environmental Kuznets curve for energy consumption in Norway at some time during the period 1835-2019. The paper investigates the EKC in two dimensions. Firstly, it examines a relative EKC. It is measured by the relationship between energy intensity (EI) and gross domestic product per capita. This is done by establishing annual series of energy intensity, i.e. energy consumption divided by GDP in fixed prices for the entire period. Secondly, an absolute EKC is considered, measured by energy consumption per capita compared to GDP per capita. It should be noted that the environmental effect of energy depends on its production sources. By the introduction of hydroelectric power from the late 1800s, Norwegian mainland energy consumption became cleaner and more environmentally friendly, while coal had the opposite effect.

The data are compiled from research into historical series of energy consumption and GDP combined with more recent data from Statistics Norway. By looking at the time series of EI, one can find an evident and almost constant negative trend in the series, meaning that $\mathrm{EI}$ is falling during the entire period. For the last about 70 years, i.e., 1950-2019, one can find a clearly inverted U-shaped curve. This implies that for Norway, there is a relative EKC for this latter period with a turning point and decoupling since 1975.

Looking at energy consumption per capita, a similar inverted U-shaped curve for the entire period can be found, and in particular for 1945-2019. This means there is an absolute EKC. It has a turning point and decoupling from 2002.

The paper finally proposes a polynomial regression model to test the relationship between energy intensity and energy consumption, on the one hand, and GDP per capita, on the other. These tests clearly 
confirm that both relative and absolute EKCs have been found for Norway. This suggests it is possible to combine wealth of nations and sustainable economic growth.

\section{AUTHOR CONTRIBUTIONS}

Conceptualization: Ola Honningdal Grytten, Magnus Lindmark, Kjell Bjørn Minde.

Data curation: Ola Honningdal Grytten, Magnus Lindmark, Kjell Bjørn Minde.

Formal analysis: Ola Honningdal Grytten, Magnus Lindmark, Kjell Bjørn Minde.

Funding acquisition: Ola Honningdal Grytten, Magnus Lindmark, Kjell Bjørn Minde.

Investigation: Ola Honningdal Grytten, Magnus Lindmark, Kjell Bjørn Minde.

Methodology: Ola Honningdal Grytten, Magnus Lindmark, Kjell Bjørn Minde.

Project administration: Ola Honningdal Grytten, Kjell Bjørn Minde.

Resources: Ola Honningdal Grytten, Magnus Lindmark, Kjell Bjørn Minde.

Software: Ola Honningdal Grytten, Magnus Lindmark, Kjell Bjørn Minde.

Supervision: Ola Honningdal Grytten, Magnus Lindmark, Kjell Bjørn Minde.

Validation: Ola Honningdal Grytten, Magnus Lindmark, Kjell Bjørn Minde.

Visualization: Ola Honningdal Grytten, Kjell Bjørn Minde.

Writing - original draft: Ola Honningdal Grytten, Magnus Lindmark, Kjell Bjørn Minde.

Writing - review \& editing: Ola Honningdal Grytten, Kjell Bjørn Minde.

\section{REFERENCES}

1. Arrow, K., Bolin, B., Costanza, R., Dasgupta, P., Folke, C., Holling, ... Pimentel, D. (1995). Economic growth, carrying capacity, end the environment. Science, 268, 520-521. Retrieved from https:// pdfs.semanticscholar.org/01ea/ c2548adbb9f2adcf0c414d3c27d20ec609dd.pdf

2. Arrow, K., Dasgupta, P., Goulder L., Daily, G., Ehrlich, P., Heal, G., ... Walker, B. (2004). Are we consuming too much? Journal of Economic Perspectives, 18(3), 147-172. Retrieved from http:// stephenschneider.stanford.edu/ Publications/PDF_Papers/Arrow_JEP_2004.pdf

3. Auty, R. (1985). Materials intensity of GDP: research issues on the measurement and explanation of change, Resource Policy, 11(4), 275 283. http://doi.org/10.1016/0301 4207(85)90045-5

4. Beckermann, W. (1992). Economic Growth and the environment. Whose growth? Whose environment? World Development, 20(4), 481-496. https://doi. org/10.1016/0305-750X(92)90038$\mathrm{W}$

5. Bhagawati, J. (1993). The case for free trade. Scientific Ameri- can, (11), 42-49. https://doi. org/10.7916/D8TH8XJ1

6. Bimonte, S. (2009). Growth and environmental quality: Testing the double covergence hypothesis. Ecological Economics, 68(8-9), 2406-2411. https://doi.org/10.1016/j.ecolecon.2009.03.020

7. Bimonte, S., \& Punzo, L. F. (2005). Environmental policy options in the multi-regimes framework. In L. Leskow, M. Puchet and L. F. Punzo (Eds.), New Tools of Economic Dynamics. Springer: New York. https://doi.org/10.1007/3540-28444-3_17

8. Bruvoll, A., \& Fæhn, T. (2005) Økonomisk vekst - medisin mot dårlig miljø? Økonomisk forum, 59(2), 34-43. (In Norwegian). Retrieved from https:// ssb.brage.unit.no/ssb-xmlui/ handle/11250/177888

9. Chertow, M. R. (2000). The IPAT Equation and Its Variants. Journal of Industrial Ecology, 4(4), 13-29. https://doi. org/10.1162/10881980052541927

10. Ciegis, R., Streimikiene, D., \& Zavadskas, E. K. (2008). The use of the environmental Kuznets curve; environmental and economic implications. International Journal of Environment and Pollution, 33(2/3), 313-335. https://doi. org/10.1504/IJEP.2008.019401

11. Copeland, B. R., \& Taylor, M. S. (2004). Trade, Growth, and the Environment. Journal of Economic Literature, 42(1), 7-71. https://doi. org/10.1257/002205104773558047

12. Dinda, S. (2004). Environmental Kuznets Curve Hypothesis: A Survey. Ecological Economics, 49(4), 431-455. https:// doi.org/10.1016/j.ecolecon.2004.02.011

13. Gales, B., Kander, A., Malanima, P., \& Rubio, M. (2007). North versus South: Energy transition and energy intensity in Europe over 200 years. European Review of Economic History, 11(2), 219253. https://doi.org/10.1017/ S1361491607001967

14. Grimstad, M. L. (2019). Hva er energiintensitet, og hvordan kan den måles? Oslo: Statistics Norway. Documents, 24, 1-19. (In Norwegian). Retrieved from https:// www.ssb.no/energi-og-industri/ artikler-og-publikasjoner/_attachment $/ 390074$ ? ts $=16 \mathrm{~b} 6 \mathrm{e} 69 \mathrm{c} 168$ 
15. Grossman, G. M., \& Krueger, A. B. (1991). Environmental impacts of the North American Free Trade Agreement (NBER Working Paper, 3419). Retrieved from https:// www.nber.org/papers/w3914.pdf

16. Grytten, O. H. (2020). Two Centuries of Economic Growth: Norwegian GDP 1816-2020 (NHH Dept. of Economics Discussion Paper No. 10/2020). Retrieved from https://ssrn.com/abstract $=3632902$

17. Harbaugh, W. T., Levinson, A., \& Wilson, D. M. (2002). Reexamining the Empirical Evidence for an Environmental Kuznets Curve. The Review of Economics and Statistics, 84(3), 541-551. https://doi. org/10.1162/003465302320259538

18. Hartwick, J. M. (1977).

Intergenerational equity and the investment of rents from exhaustible resources. American Economic Review, 67(5), 972-974. Retrieved from http://www.jstor. org/stable/1828079

19. Johansson, P. O., \& Kriström, B. (2007). On a clear day you might see an environmental Kuznets curve. Environmental and Resource Economics, 37(1), 77-90. https://doi.org/10.1007/s10640007-9112-9

20. Kander, A. (2002) Economic growth, energy consumption and CO2 emissions in Sweden 18002000. Lund Studies in Economic History 19. Retrieved from http:// www.environmentandsociety.org/ $\mathrm{mml} /$ economic-growth-energyconsumption-and-co2-emissionssweden-1800-2000

21. Kander, A., Malanima, P., \& Warde, P. (2013). Power to the People: Energy in Europe over the Last Five Centuries. Princeton: Princeton University Press. Retrieved from https://press.princeton.edu/books/ hardcover/9780691143620/powerto-the-people

22. Koilo, V. (2019a). Evidence of the Environmental Kuznets Curve: Unleashing the Opportunity of Industry 4.0 in Emerging Economies. Journal of Risk and Financial Management, 12(3), 122. https:// doi.org/10.3390/jrfm12030122
23. Koilo, V. (2019b). Sustainability issues in maritime transport and main challenges of the shipping industry. Environmental Economics, 10(1), 48-65. https://doi. org/10.21511/ee.10(1).2019.04

24. Kunnas, J., \& Myllyntaus, T. (2009). Postponed leap in carbon dioxide emissions: The impact of energy efficiency, fuel choices, and industrial structure on the Finnish energy economy 1800-2005. Global Environment, 2(3), 154189. https://doi.org/10.3197/ ge.2009.020307

25. Lindmark, M., \& Minde, K. B. (2018). Energy consumption in the Norwegian mainland economy 1835-2012. Heimen, 55(2), 157 177. https://doi.org/10.18261/ issn.1894-3195-2018-02-05

26. Maddison, A. (2007). Contours of the World Economy, 1-2030 AD. Essays in Macro-Economic History. Oxford: Oxford University Press.

27. Malenbaum, W. (1978). World Demand for Raw Materials in 1985 and 2000. New York: McGraw-Hill.

28. Meadows, D. H., Meadows, D. L., Randers, J., \& Behrens, J. (1972). The Limits to Growth. New York: University Books.

29. Mills, J. H., \& Waite, T. A. (2009). Economic prosperity, biodiversity conservation, and the environmental Kuznets curve. Ecological Economics, 68(7), 20872095. https://doi.org/10.1016/j. ecolecon.2009.01.017

30. Nakicenovic, N., Grubler, A., \& McDonald, A. (Eds.) (1998). Global Energy Perspectives. Cambridge University press, Cambridge, UK. https://doi.org/10.1002/ ep.670180305

31. Nemat, S. (1994). Economic development and environmental quality: an econometric analysis. Oxford Economic Papers, 46(2), 757-773. Retrieved from https:// www.jstor.org/stable/2663498

32. Panayotou, T. (1993). Empirical tests and policy analysis of environmental degradation at different stages of economic development. Geneve: ILO, Technology and Employment Program.
33. Rothman, D. S. (1998). Environmental Kuznets Curves - real progress or passing the buck? A case for consumptionbased approaches. Ecological Economics, 25(2), 177-194. https://doi.org/10.1016/S09218009(97)00179-1

34. Schurr, S., \& Netschert, B. (1978). Energy in the American economy, 1850-1975, an economic study of its history and prospects. John Hopkins Press: Baltimore.

35. Skoglund, T. (2009). Bruttonasjonalprodukt etter noering og sluttanvendelse i historisk nasjonalregnskap. Beregninger for 1946-1949. Oslo: Statistics Norway. (In Norwegian). Retrieved from https://www.ssb.no/a/publikasjoner/pdf/notat_200928/notat_200928.pdf

36. Smil, V. (2000). The energy question, again. Current History, 99(641), 408-412.

37. Smil, V. (2016). Examining energy transitions: A dozen insights based on performance. Energy Research \& Social Science, 22(1), 194-197. https://doi.org/10.1016/j. erss.2016.08.017

38. Spangenberg, J. H. (2001). The Environmental Kuznets Curve: A Methodological Artefact? Population and Environment, 23(2), 175-191. Retrieved from https://www.academia. edu/339424/The Environmental Kuznets_Curve_A_Methodological_Artefact

39. Statistics Norway. (2020). Retrieved from https://www.ssb. no/statbank/table/08205/

40. Stern, D. I. (2004). The Rise and Fall of the Environmental Kuznets Curve. World Development, 32(8), 1419-1439. https:// doi.org/10.1016/j.worlddev.2004.03.004

41. Stoltz, G. (1955). Economic Survey, 1900-1950. Oslo: Statistics Norway.

42. Tilton, J. E. (1990). The OECD countries: demand trend setters. In J. E. Tilton (Ed.), World Metal Demand: Trend and Prospects. Resources for the Future (pp. 3576). Washington DC. 
43. Uchiyama, K. (2016).

Environmental Kuznets Curve

Hypothesis and Carbon Dioxide Emissions. New York: Springer.

44. UN. (1987). Report of the World Commission on Environment and Development: Our Common Future. Transmitted to the General Assembly as an Annex to document A/42/427 - Development and International Co-operation: Environment. Retrieved from https://sswm.info/sites/default/files/ reference_attachments/UN\%20 WCED\%201987\%20Brundtland\%20Report.pdf

45. Warde, P. (2019). Firewood consumption and energy transition: a survey of sources, methods and explanations in Europe and North America. Historia Agraria, 77(1), 7-32. Retrieved from http://www. historiaagraria.com/FILE/articulos/RHA77_warde.pdf
46. Wilkinson, R. G. (1973). Poverty and progress: an ecological model of economic development. London: Methuen.

47. Williams, R. H., Larson, E. D., \& Ross, M. H. (1987). Materials, Affluence, and Industrial Energy Use. Annual Review of Energy, 12(1), 99-144. https:// doi.org/10.1146/annurev. eg.12.110187.000531 